УДК 373.3.017.31.502.2

DOI https://doi.org/10.32782/apv/2021.2.13

\title{
Руслана РОСЛАВЕЦЬ
}

кандидат педагогічних наук, доцент, доцент кафедри теорії та методики початкової освіти, Волинський національний університет імені Лесі Українки, просп. Волі, 13, м. Луцьк, Волинська обл., Україна, 43025

ORCID: 0000-0003-4564-4208

Бібліографічний опис статті: Рославець, Р. (2021). Роль спостережень у творчому розвитку молодших школярів.ActaPaedagogica Volynienses, 2, 81-86, doi:https://doi.org/10.32782/apv/2021.2.13

\section{РОЛЬ СПОСТЕРЕЖЕНЬ У ТВОРЧОМУ РОЗВИТКУ МОЛОДШИХ ШКОЛЯРІВ}

У статті висвітлено значення методу спостереження в освітньому процесі навчання та виховання учнів молодшого шкільного віку, а також під час ознайомлення школярів з навколишньою природою. Проаналізовано поняття спостереження як методу навчання, його місие в організації навчально-виховного процесу з молодшими школярами та можливості застосування методу спостереження під час навчальних занять, прогулянок та уроків-екскурсій. Звернено увагу на роль спостережень під час проведення виховних заходів. Доведено до усвідомлення молодших школярів про те, щуо, спостерігаючи те чи інше явщще чи об 'єкт оточуючого середовища, дитина не тільки поглиблює свої знання, але й активніше мислить, здобуває певні навички та вміння в охороні та збереженні довкілля, отримує певний досвід.

Схарактеризовано оптимальний характер методики проведення спостережень за об'єктами та явищами природи молодиими школярами.

Експериментальні та методичні дослідження трунтувались на психологічних та педагогічних особливостях, характерних для дітей молодшого шкільного віку, а теоретичні та практичні питання були сформульовані у доступній для них формі. Такий підхід сприяє розвитку в молодших школярів творчості та ширще бачити навколишній світ і розуміти його. Пропонуються методи ознайомлення з різноманітними явищами природи під час спостереження за нею.

У статті подаються вчителям початкових класів окремі практичні поради, а також нагадування про те, щзо учнівські спостереження мають бути иілеспрямованими, безперервними, послідовними, систематичними, зв'язними та логічними.

Так як конститутивна роль в організації проведення методу спостереження у початковій школі належить учителеві, то в статті подано, як саме він повинен навчити учнів початкових класів правильно, безпомилково спостерігати за явищами навколишньої природи, робити певні узагальнення $і$ висновки, показувати молодшим школярам місцеву природу в усій красі, складності й діалектичній єдності, розвивати в них інтерес і любов до оточуючого світу, природи, прищеплювати їм навички дослідницької та практичної діяльності.

Ключові слова: метод, спостереження, розвиток мовлення, творчий розвиток, спостережливість, метод навчання, метод виховання.

\section{Ruslana ROSLAVETS}

PhD in Pedagogy, Associate Professor, Senior Lecturer at the Department of Theory and Methods of Primary Education, Lesya Ukrainka Volyn National University, 13 Voli ave., Lutsk, Volyn region, Ukraine, 43025

ORCID: 0000-0003-4564-4208

To cite this article: Roslavets, R. (2021). Rol sposterezhen u tvorchomu rozvytku molodshykh shkoliariv [The role of observations in the creative development of junior schoolchildren]. Acta Paedagogica Volynienses, 2, 81-86, doi: https://doi.org/10.32782/apv/2021.2.13

\section{THE ROLE OF OBSERVATIONS IN THE CREATIVE DEVELOPMENT OF JUNIOR SCHOOLCHILDREN}

The article highlights the importance of the method of observation in the educational process of teaching and educating primary school students, as well as during the acquaintance of students with the surrounding nature. The concept of observation as a method of teaching, its place in the organization of the educational process with younger students and the possibility of applying the method of observation during classes, walks and lessons-excursions are analyzed. Attention is paid to the role of observations during educational activities. It is brought to the attention of younger students that by observing a phenomenon 
or object of the environment, the child not only deepens his knowledge, but also thinks more actively, acquires certain skills and abilities in the protection and preservation of the environment, gains some experience.

The optimal nature of the method of observation of objects and phenomena of nature by junior schoolchildren is characterized.

Experimental and methodological research was based on psychological and pedagogical features characteristic of children of primary school age, and theoretical and practical questions were formulated in a form accessible to them. This approach promotes the development of creativity in younger students and a broader view of the world around them and understand it. Methods of acquaintance with various phenomena of the nature during observation of it are offered.

The article provides some practical advice to primary school teachers, as well as reminders that student observations should be focused, continuous, consistent, systematic, coherent, and logical.

Since the constitutive role in the organization of the method of observation in primary school belongs to the teacher, the article presents how he should teach primary school students to correctly, unmistakably observe the phenomena of nature, make certain generalizations and conclusions, show younger students local nature throughout beauty, complexity and dialectical unity, to develop in them interest and love for the surrounding world, nature, to instill in them skills of research and practical activity.

Key words: method, observation, speech development, creative development, observation, teaching method, method of education.

Чільне місце у новому Державному стандарті освіти займають методи пізнання природи, зокрема спостереження за змінами у навколишньому середовищі, за іiі явищами, за динамікою росту і розвитку змін у довкіллі. У цьому документі акцентується увага на формуванні природничої компетентності учнів, що можна здійснити через засвоєння ними системи інтегрованих знань про світ, що нас оточує та розвиток пізнавальної активності.

В контексті формування спостережливості молодших школярів центральне місце належить вчителю. Власне він і займається організацією цієї роботи.

У пошуках шляхів удосконалення екологічного виховання, знання і освіти в останній період вчені все більше звертаються до концепцій «Виховання на природі», яке займає значне місце в історії психології та педагогіки. Ще античні мислителі (Демокріт, Аристотель) вважали, що людина і ремеслу, і мистецтву вчиться у природи: у павука - ткацтву, у ластівки - як будувати будинок, у співучих птахів - співу і т.д. Видатний педагог і психолог К.Д. Ушинський значну увагу в процесі виховання і освіти приділяв «живим, сильним виховуючим душу враженням природи», умінню бачити іiі, спостерігати за нею. Завдання «повернути і відкрити погляду» явища і процеси природи має не лише естетичне значення. Воно - смисложиттєвість для сучасної людини. Тому проблема розвитку в учнів спостереження за природою досить актуальна, оскільки це сприятиме підвищенню екологічної культури молодого покоління. Звернення до природного оточення, як правило, вносить у процес навчання і виховання елемент різноманітності, робить його багатогранним і емоційно насиче- ним. Ця проблема вивчалася багатьма дослідниками-психологами (Д.Б. Богоявленська, Г.С. Костюк, С.Л. Рубінштейн, Н.І. Лисіна, Л.В. Маркова та ін.), які вважали, що розвивати пізнавальну активність дітей у процесі спостереження за природою - це означає розвивати у них готовність до діяльності. Той психічний стан, який передує діяльності, породжує іiі і супроводжує, надаючи ій активного характеру, що дуже важливо при формуванні якостей особистості, вихованні іiі екологічної культури. Пізнавальна активність, як правильно вказують Н.С. Лейтес, Е.А. Голубєва,це міра взаємодії суб'єкта 3 навколишнім середовищем. Проте немає нічого більш невизначенішого, ніж спроба відповісти на питання, як правильно організувати і провести безпосереднє спостереження учнями різних біологічних явищ під час екскурсій, туристських походів, роботи на шкільній навчально - дослідній ділянці, тобто, як розвивати їх пізнавальну активність.

Великий вклад у розвиток, впровадження спостереження в освітню роботу зробили наші сучасні педагоги О.Д. Савченко та Т.М. Байбара. Зокрема, відомий педагог наголошує, що спостереження у навколишньому світі допомагає глибше вдивлятися у природу, ширше бачити іï, розуміти взаємозв'язок між явищами, що у ній відбуваються, між предметами довкілля, розрізняти, порівнювати та розуміти які зміни відбуваються у навколишньому середовищі, коли вони наступають, чому, як суспільство впливає на їі розвиток чи занепад.

А посібник Т.М. Байбари - один із найперших ліг на стіл вчителя 3 питань методики навчання природознавства, розглядає та методично навчає готувати майбутніх вчителів початкової школи до реалізації навчання спостережливості учнів. 
У природі, як відомо, під впливом зовнішнього середовища безперервно відбуваються зміни в розвитку кожного живого організму. Так, наприклад, навесні бубнявіють бруньки на деревах і кущах, згодом розпускається листя, зацвітають квітки, на початку літа зав'язуються плоди, в кінці його - вони достигають, а восени опадає листя. За цими та іншими змінами треба вчити учнів систематично спостерігати. У колі зору можуть бути садові, городні та польові культури, трави, квіти, а також тварини, птахи, риби, комахи. Вивчаються i реєструються сезонні явища ( розвиток і зміни ), що відбуваються під впливом зовнішнього середовища.

Головна роль в організації проведенні спостережень у школі належить учителеві. Він має навчити дітей правильно спостерігати явища природи, робити певні узагальнення і висновки, показати їм місцеву природу в усій красі, складності й діалектичній єдності, розвивати в них інтерес і любов до природи, прищеплювати їм навички дослідницької роботи.

Справитись 3 таким досить складним завданням зможе педагог тоді, коли матиме теоретичні знання і практичні навички, а також володітиме методикою проведення учнівських спостережень.

У цій статті хочемо дати вчителям деякі практичні поради, а також нагадати, що учнівські спостереження мають бути цілеспрямованими i систематичними. Розпочинати тривалі спостереження за сезонними явищами природи, над розвитком рослин та тварин можна тільки тоді, коли учні вже набудуть деяких навичок цієї роботи на уроках. Тому на перший план висувається завдання навчити дітей правильно сприймати об'єкти і явища природи, допомагати їм усвідомити розвиток навколишнього природного оточення, помічати найістотніше.

Як свідчать результати нашого дослідження, успіх роботи з розвитку спостереження залежить від детальної іiі підготовки. Природно, що вчитель повинен спочатку сам обстежити околиці та виділити місце для проведення спостережень. Таких місць може бути декілька, бо рідко буває, щоб на одній ділянці знаходились всі потрібні для вивчення об'єкти. Бажано, щоб вони знаходились недалеко від школи, в такому разі регулярні спостереження можна проводити без будь-яких ускладнень.

Проте роботу слід розпочинати 3 докладного ознайомлення обраної місцевості. Кожну ділянку, на якій проводитимуться спостереження, треба докладно охарактеризувати. При цьому, наприклад, треба подати такі відомості: де територіально знаходиться місцевість ( назва області, міста, села); ії загальна характеристика ( поле, ліс, долина, річки, низина, болото і т.п); місцеположення ділянки ( на горбку, на схилі ); чи є близько річка, озеро, ставок; чи є навколо будинки або господарські будівлі; чи є поблизу підприємства, які виділяють шкідливі речовини; характеристика грунту.

Після цього класовод може організувати спостереження учнів відповідно до розробленого плану та програми. Найпоширенішою у шкільній практиці формою такої роботи є екскурсії. Вони відкривають широкі можливості для різностороннього вивчення природи рідного краю. Підготовку учнів до екскурсій класовод повинен розпочати заздалегідь. Насамперед він складає докладний план проведення екскурciï, в якому визначає мету, перелічує всі етапи роботи, подає зміст завдань для самостійного виконання учнями, зазначає об'єкти спостережень, намічає контрольне запитання для перевірки ступеня усвідомлення дітьми навчального матеріалу. Після цього вчитель ознайомлює школярів 3 планом екскурсії, визначає час походу, маршрут, засоби пересування, радить їм відповідним чином одягнутися. Перед виходом на екскурсію треба обов'язково перевірити готовність до походу кожного учня.

Під час екскурсії вчитель коротко розповідає про намічені об'єкти спостережень і учні приступають до роботи. Дані спостережень діти відразу занотовують у журналі або в зошиті. Наприклад, у дерев і ягідних кущів вони відмічають такі фази розвитку: набубнявіння бруньок, розпускання квіткових бруньок, початок розгортання перших листочків, повне розпускання листя, початок опадання пелюсток, кінець цвітіння, початок зав'язування плодів, достигання плодів, початок та кінець збирання плодів, початок та кінець листопаду.

Результати наших досліджень свідчать, що дуже цікавими об'єктами для спостережень у школі є квіти, різноманітність видів і сортів яких привертає увагу учнів. Розведення, вирощування і вивчення квітів має велике значення для виховання школярів, формування в них відчуття прекрасного, а й згодом і для дальшого розвитку квітникарства в нашій країні. 
3 великим бажанням і цікавістю учні молодшого шкільного віку ведуть спостереження за птахами. Найкращий час для цих спостережень 3 перших днів березня і до травня включно. За птахами, що зимують в цій місцевості, слід спостерігати з часу їх появи восени і аж до відлітання їх весною, хоч осінньо-зимові спостереження дещо складніші для молодших школярів.

Доцільно спостерігати за тими птахами, які приносять користь сільському господарству, знищують шкідників у садах, парках, лісах тощо (дятел, зозуля, одут, синиця, деркач, шпак та ін.). Велике задоволення дістають діти, спостерігаючи за співучими птахами, такими як солов'ї, вільшанки, зяблики, жайворонки, а також водоплавними птахами таких рядів:

- Гусеподібні (Anseriformes) (Сірий гусак, крижень, лебеді, гоголь, чирок, гага звичайна, домашні качки й гуси);

- Гагароподібні (Gaviiformes) (Гагара біло дзьоба, гагара білошия);

- Пірникозоподібні

(Podicipitiformes)

(Пірникоза);

- Пеліканоподібні (Pelecaniformes) (Пелікан);

- Пінгвіноподібні (Sphenisciformes) (Пінгвін);

- Деякі Журавлеподібні (Gruiformes), (степовий та сірий журавель, дрохва, стрепет;

Нижче подаємо перелік тих фактів, які треба відмічати у журналі, спостерігаючи за птахами.

1. Приліт птахів у різні пори року (навесні, влітку, восени, взимку).

2. Початок і кінець співу птахів. Варто простежити при цьому за тими явищами, які відбуваються водночас у природі. Так, наприклад, вважають, що припинення співу солов'я збігається з викиданням колосу ячменем.

3. Як і де саме ті чи інші птахи будують гнізда. Це дасть можливість оберігати гнізда від різних хижаків. Одночасно треба поширювати хорошу традицію серед учнів - створювати для птахів штучні гнізда.

4. Кількість гнізд на території саду чи парку. Це дасть можливість здійснити практичні заходи, пов'язаних із створенням відповідних умов для приваблювання птахів у ту чи іншу місцевість.

5. Дата відкладання яєць, початок їх висиджування та вилуплення пташенят. В цей час бажано підрахувати, скільки разів на день птахи годують своїх пташенят і як та де вони добувають корм.
6. Відліт молодих пташенят 3 гнізда. У перші дні вильоту пташенята ще не можуть цілком самостійно здобувати собі їжу. Отже, слід у записах відмітити ставлення батьків до молоді після відльоту з гнізда, їх участь у добуванні їжі для пташенят (чи підгодовують, коли і як, чи охороняють від хижаків та ін.)

7. Час відльоту птахів з певної місцевості. Відомо, що різні птахи по-різному готуються до відльоту. Бажано на підставі старанних спостережень охарактеризувати поведінку тих чи інших птахів перед цією подією в їхньому житті, а саме: коли почалось їх гуртування, коли вони почали залишати свої гнізда та ін.

Після кожного спостереження необхідно проводити бесіди з учнями з метою виявлення знань про різні об'єкти в природі. Входячи в життя дитини 3 першими відчуттями під час спостереження, сприйняттями, поняттями, уявленнями, природа стає для неї наочним мірилом цінностей, джерелом багатств. У цьому факті закладено величезні можливості становлення гармонійної, всебічно розвиненої людини. «Природа - колиска дитячої думки, говорив В.Сухомлинський, - і треба прагнути, щоб кожна дитина пройшла школу дитячого мислення. Дорого, дуже дорого доводиться розплачуватися за забуття цісї істини $[5 ; 539]$.

Дослідження цієї проблеми дозволила виявити, що живі явища, живе споглядання, активне спілкування дитини з природою не можна замінити ніякою інформацією, яку несуть технічні засоби. У природі закладені в доступній для дитини формі прості і разом з тим дуже складні речі, предмети, факти, явища, залежності, закономірності, інформацію про які нічим не можна замінити, тому що вона відповідає саме світу дитячої природи; тому що інформація про ці речі, предмети, явища $є$ тим світом, в який входить сама дитина. Перше джерело уявлень, понять, думок, узагальнень, суджень діти подають у своїх віршах, казках, оповіданнях. Для прикладу (після проведеного нами з учнями спостереження за змінами в природі взимку) наведемо оповідання, яке написала Марійка (2 клас) і назвала його «Сніжинки».

Був чудовий зимовий день. В повітрі хороводом кружляли сніжинки, ніби виспівуючи веселу зимову пісеньку. Вони були такі гарні і кумедні! Я довго спостерігала за ними. Мені стало теж весело і я заспівала. (Після цього 
оповідання Марійка намалювала себе в розкішній сукні. Вона танцює і співає).

Таким чином, природа -це джерело і водночас світ, "дитинство думки", яке так необхідне, неминуче і закономірне для нормального розумового розвитку людини. I цього не можна забувати. Тепер, коли в школу приходить багато нового і потрібного, одночасно не можна відмовлятися від речей, які повинні залишитися в нашому житті такими ж постійними, як повітря, небо, сонце.

Своєрідні заняття з розвитку спостереження за природою можна назвати уроками мислення. Кожне таке заняття має свою тему, передбачає конкретне поле речей; явищ для спостереження. Проте, дуже важливо не завантажити дитину безліччю свіжих вражень, оскільки школяр заглиблюється подумки в якусь, здавалося б, незначну деталь, зосереджує на ній всю увагу, забуває про все інше, сфера його спостережень ніби звужується, звичайно, на короткий час.

Проводячи спостереження, тематикою яких були: «Як квіти зустрічають схід сонця», «Промені сонця грають у краплинах роси», «Як співає жайворонок», «Як ластівка будує гніздо» та ін. вчитель повинен надавати виняткового значення тому, щоб кожна з названих тем несла учневі безліч відкриттів, зроблених ним самостійно. Учень пізнає себе як активну творчу силу, переживає почуття гордості за те, що все це, він побачив сам. I чим більше осягають учні насолоду цієї праці - відкривати і мислити, тим органічніше зливається їх розум та воля. Це дуже важливо в шкільній роботі: осягнення цього на власному досвіді сприяє тому, що воля дисциплінує розум. Людина з малих років учиться ставити інтелектуальні цілі, виробляє здатність примушувати себе думати.

Немає в усій нашій шкільній роботі складнішого і важчого завдання, ніж досягти того, щоб учень умів примусити себе думати. За словами В.О. Сухомлинського «Це ті сім печа- ток багатьох педагогічних таємниць, які вчителеві в практичній роботі так важко осягнути» [5; 541]. Саме під час спостереження за природою учні вчаться думати, відчувають нелегку насолоду цієї праці, «стають гордими відкривачами» причин, наслідків, зв'язків між явищами природи. Так, під час заняття на тему: «Як квіти зустрічають схід сонця учениця (3 клас) Юля розповідає про сонце в поетичній формі: «У віконце світить сонце, ніби соняшник ясний. I воно таке красиве, - справжній м'ячик золотий!»

Учні помічають дивні речі: «квітучі головки соняшника здригаються, готуючись повернутися до сонця», «соняшник шукає сонця» (це слова маленької людини) і задумуються: що ж у ній, у цій дивній рослині, є таке, що примушує iї линути до світла?

Отже, результати нашого дослідження дозволяють зробити деякі висновки. Цікаву властивість має ця книга природи: чим більше відкриттів зробила маленька людина, чим глибше радість мислення вона пережила під час спостереження за природою, тим більше ставить запитань: чому, як, що таке, і тим бадьоріші, свіжіші духовні сили, спрямовані на те, щоб пізнати, знайти відповідь. Крапля думки про природу породжує могутню повноводу річку думки. Потреба думати, спостерігати загострює допитливе зацікавлене бачення світу, бажання досліджувати, міркувати. Думки і почуття, що хвилюють дитину, матеріалізуються в слові, а слово, якщо воно вже ввійшло в духовний світ школяра, стає стимулом нової думки: йому хочеться сказати яскраво, виразно, точно - кінець кінцем сказати про красиве красиво. Після таких спостережень учні складають твори, оповідання, вірші, казки (деякі з них ми приводили вище). Ця праця є для них однією 3 найбажаніших і разом 3 тим напружених різновидів того мислення, в якому на перше місце виступають воля і прагнення.

\section{ЛIТЕРАТУРА:}

1. Бойко Є. Екологічні ігри. Рідна школа. 1995. № 10-11. С. 40-41.

2. Волкова А.С. Екологічне виховання школярів. Початкова школа. 2002. № 8. С. 6.

3. Вчити любити природу: Про стан природоохоронного навчання та виховання в навчальних закладах України. Рідна природа. 1992 №2-3. С. 43-46.

4. Коваль Н.С. Люби і бережи рідну природу: матеріали для екологічного виховання учнів початкових класів. Початкова школа. 1991. № 1. С. 14-18.

5. Сухомлинський В.О. Вибрані твори в 5 т. Т. 5. Київ : 1977. С. 539. 


\section{REFERENCES:}

1. Boyko, E. (1995). Ekolohichni ihry [Ecological games]. Ridna shkola-Native school, 10-11, 40-41 [in Ukrainian].

2. Volkova, A.S. (2002). Ekolohichne vykhovannia shkoliariv [Ecological education of schoolchildren]. Pochatkova shkola - Elementary School, 8, 6 [in Ukrainian].

3. Vchyty liubyty pryrodu: Pro stan pryrodookhoronnoho navchannia ta vykhovannia v navchalnykh zakladakh Ukrainy. Learn to love nature: About the state of environmental education and education in educational institutions of Ukraine (1992). Ridna pryroda - Native nature. 2-3. 43-46 [in Ukrainian].

4. Koval, N.S. (1991). Liuby i berezhy ridnu pryrodu: materialy dlia ekolohichnoho vykhovannia uchniv pochatkovykh klasiv [Love and protect native nature: materials for the environment education of primary school students]. Pochatkova shkola - Elementary School, 1, 14-18 [in Ukrainian].

5. Sukhomlinsky, V.O. (1977). Vybrani tvory [Selected works]. Vol. 5. Kyiv [in Ukrainian]. 